ISSN 2338-1523

E-ISSN 2541-576X

Volume 7 No. 1

Mei 2019

\title{
SISTEM INFORMASI PENGOLAHAN DATA PRODUKSI IKAN PADA KANTOR BALAI BENIH IKAN (BBI) TALANG KEMULUN MENGGUNAKAN BAHASA PEMROGRAMAN VB. NET (Studi Kasus pada Kantor Balai Benih Ikan (BBI) Talang Kemulun)
}

\author{
Radike \\ Sekolah Tinggi Manajemen Informatika (STMIK) GICI Batam \\ Email, Khinchay11@Gmail.com
}

\begin{abstract}
ABSTRAK
Balai Benih Ikan ( BBI ) Talang Kemulun adalah sarana Pemerintah untuk menghasilkan benih ikan dan sekaligus untuk membina Usaha Pembenihan ikan Rakyat ( UPR ) yang tersebar dihampir seluruh Kabupaten Kerinci Provinsi Jambi, BBI dalam menjalankan bisnis ini memproduksi sendiri berbagai jenis ikan berdasarkan perkiraan Kepala UPTD Balai Benih Ikan ( BBI ). Dalam proses pengambilan data dilakukan langsung pada Kantor Balai Benih Ikan (BBI) Talang Kemulun untuk mendapatkan data dan untuk mengetahui kendala-kendala apa saja yang dihadapi oleh Kantor Balai Benih Ikan (BBI) Talang Kemulun tersebut di dalam proses pengolahan data produksi ikan. Pada sistem yang sedang berjalan, pengolahan data produksi ikan masih dilakukan secara manual sehingga informasi yang dihasilkan kurang efisien dan efektif. Adapun usaha-usaha untuk menerapkan sistem tersebut adalah dengan cara membandingkan sistem yang lama dengan sistem yang baru, untuk merombak dari sistem yang lama kesistem yang baru telah terlebih dahulu mendapatkan perbandingan antara kedua sistem yang diterapkan dan memilih dari sistem tersebut yang rasanya akan membawa keuntungan bagi Kantor Balai Benih Ikan (BBI) Talang Kemulun.
\end{abstract}

Kata kunci : Sistem Pengolahan Data, Ikan, Vb. Net

\section{PENDAHULUAN}

\subsection{Latar Belakang}

Perkembangan dunia zaman sekarang ini diberbagai bidang kehidupan baik dalam bidang ekonomi, sosial, budaya, politik dan dunia pendidikan selalu dituntut untuk memberikan segala sesuatu dengan cepat, tepat dan akurat baik dalam pemprosesan data maupun dalam penyajian informasi yang dibutuhkan.

Seiring dengan derap langkah pembangunan dewasa ini bahwa pekerjaan yang dihadapi manusia kian hari kian rumit. Untuk itulah setiap perusahaan, industri baik pemerintah maupun swasta yang ada di indonesia harus mengikuti perkembangan ilmu pengetahuan dan teknologi. Salah satu bentuk kemajuan perkembangan IPTEK tersebut adalah dalam bidang ilmu informasi yang menggunakan teknologi komputer.

Sehubungan dengan hal ini tersebut teknologi komputer merupakan salah satu alat bantu pengolahan data agar data tersebut dapat berguna dalam pengambilan suatu keputusan penting yang dapat diakses/dimanfaatkan oleh orang atau organisasi baik pemerintah maupun swasta untuk mengantisifasi tuntutan diatas dalam masa sekarang ini. Hal ini disebabkan komputer melakukan pekerjaan yang berulang-rulang dalam waktu yang relatif

JURSIMA https://ejournal.giciku.ac.id/

Jurnal Sistem Informasi dan Manajemen 
ISSN 2338-1523

E-ISSN 2541-576X

Volume 7 No. 1

Mei 2019

singkat dan mampu menyajikan informasi dengan cepat, tepat, akurat dan juga dalam komputerisasi sekarang ini, betapa pentingnya jasa dan informasi disamping ilmu lainnya. Hasil-hasil yang dicapai dalam bidang ilmu pengetahuan dan teknologi mengakibatkan banyaknya perubahanperubahan yang terjadi terutama dibidang administrasi dan manajemen.

Pada Kantor Balai Benih Ikan (BBI)

Talang Kemulun telah menggunakan komputer untuk mendapatkan laporan data ikan setiap bulannya. Pentingnya peranan komputer dalam sistem informasi disebabkan besarnya volume data yang akan diolah pada suatu bidang. Kantor Balai Benih Ikan (BBI) Talang Kemulun pengolahan produksi ikan masih belum efektif.

Didasari atas hambatan-hambatan dan kelemahan diatas penulis tertarik untuk mendesain suatu sistem baru dengan mengaplikasikan bahasa pemrograman VB. Net dalam pengolahan data produksi ikan.

\subsection{Perumusan Masalah}

Perumusan masalah yang akan penulis ajukan disini adalah :

1. Bagaimana jika suatu sistem/cara yang belum efektif di implementasikan dengan penggunaan komputer.

2. Apakah dengan adanya sistem baru ini akan mempermudah dan menjadi efisien pada user yang membutuhkannya ?

3. Rumitnya melakukan perbaikan atau penghapusan data produksi padi sawah.

\subsection{Ruang Lingkup Penelitian}

Berdasarkan latar belakang dan rumusan masalah dalam penulisan skripsi ini maka menghindari penyimpangan dalam penelitian ini penulis hanya membatasi objek prosedur atau sistem yang mana pada JURSIMA https://ejournal.giciku.ac.id/ Jurnal Sistem Informasi dan Manajemen penelitian ini hanya dibatasi Pengolahan Data Produksi ikan pada Kantor Balai Benih Ikan (BBI) Talang Kemulun

\subsection{Tujuan Dan Manfaat Penelitian}

Adapun manfaat dan tujuan panelitian yang penulis lakukan adalah sebagai berikut :

Tujuan Penelitian :

a. Menerapkan sistem komputerisasi sebagai alat bantu atau aplikasi dalam mempermudah pengolahan data.

b. Untuk menerapkan penggunaan teknologi informatika.

Manfaat Penelitian :

Disini penulis mendapat banyak manfaat dari penelitian ini diantaranya adalah :

1. Manfaat Bagi Penulis

Untuk mengetahui sejauh mana program VB.

Net digunakan.

2. Manfaat Akademik

a. Menambah pembendaharaan dan memperkaya pengetahuan khususnya yang berkaitan dengan kualitas ilmu pengetahuan dan hubungannya dengan pemograman VB. Net di lingkungan kerja.

b. Sebagai panduan bagi pihak-pihak yang membutuhkan infomasi

3. Manfaat Bagi Instansi

Dari hasil penelitian ini diharapakan dapat memberi sumbangan pikiran dan sebagai bahan pertimbangan dalam pengambilan keputusan bagi Kantor Kepala Desa Tanjung Pauh Mudik.

\subsection{Metode Penelitian}

Dalam penyusunan penelitian ini penulis memerlukan pengumpulan data dan infomasi untuk menyelesaikan tugas skripsi ini dengan cara sebagai berikut:
a. Metode
Penelitian
Lapangan
(field
Research) 
ISSN 2338-1523

E-ISSN 2541-576X

Volume 7 No. 1

Mei 2019

Metode ini dilakukan untuk mengumpul data-data yang lengkap dan akurat maka penulis langsung mengadakan penelitian di Kantor Balai Benih Ikan (BBI) Talang Kemulun dengan melakukan pengamatan, pendekatan dan mewawancarai langsung kepada pegawai yang bersangkutan, selain itu juga penulis memperoleh dari sumbersumber yang dapat dipercaya.

b. Metode Penelitian Kepustakaan (Library Research)

Penelitian ini penulis lakukan dengan mencari, membaca, mempelajari serta memahami yang berhubungan dengan penelitian yang penulis lakukan pada Kantor Balai Benih Ikan (BBI) Talang Kemulun.

C. Metode Penelitian Laboratorium (Laboratotory Research)

Yaitu melakukan pengolahan data terhadap data-data yang telah dikumpulkan melalui penelitian, pengolahan tersebut dengan menggunakan notebook :

1. Hardware
a. Processor Intel(R) Core (TM)2 Duo $\mathrm{CPU}=2,00 \mathrm{~GB}$.
b. Monitor VGA.
c. Keyboar.
d. Mouse.
e. Printer HP deskjet F2410.

2. Software
a. Windows-7.
b. Office 2007
c. Program Vb.Net

\section{Landasan Teori}

\subsection{Konsep Dasar Sistem Informasi}

Sistem informasi dalam suatu organisasi dapat dikatakan sebagai suatu sistem yang menyediakan informasi bagi semua tingkatan dalam organisasi tersebut kapan saja diperlukan. Sistem ini menyimpan, mengambil, mengubah, mengolah dan mengkomunikasikan informasi yang diterima dengan menggunakan sistem informasi atau peralatan sistem lainnya.

\subsubsection{Pengertian Sistem Informasi}

Sistem informasi ini mengumpulkan, memproses, menyimpan, menganalis, menyebarkan informasi untuk tujuan tertentu (Tata Sutabri, S.Kom., MM, 2005).

Informasi adalah Sekumpulan fakta yang diorganisasian dengan cara tertentu sehingga mereka mempunyai arti bagi sipenerima (Tata Sutabri, S.Kom., MM, 2005).

Beberapa defenisi informasi yang disajikan oleh beberapa buku (Abdul Kadir, 2008) yaitu :

Menurut Laudon "Informasi adalah data yang telah diolah menjadi bentuk yang bermakna dan berguna bagi manusia".

Menurut Hoffer "Informasi adalah data yang diproses sedemikian rupa sehibngga meningkatkan pengetahuan seseorang yang menggunakannya".

Menurut Davis " Informasi adalah data yang telah diolah mejadi sebuah bentuk yang berarti bagi penerimanya dan bermanfaat dalam pengambilian keputusan saat ini atau saat mendatang".

Dari beberapa definisi diatas dapat diambil beberapa kesimpulan bahwa:

1) Informasi bermuara pada data.

2) Memberikan suatu nilai tambah atau pengetahuan bagi yang menggunakannya.

3) Dapat digunakan dalam pengambilan keputusan.

\subsubsection{Karakteristik Sistem}

Karakteristik sistem (Tata Sutabri, S.Kom., MM, 2005) yang dapat membedakan suatu sistem dengan sistem yang lainnya adalah sebagai berikut.

1) Komponen (Commponent)

JURSIMA https://ejournal.giciku.ac.id/ 
Proses dalam suatu sistem yang mentrasformasikan masukkan menjadi bentuk keluaran. Komponen ini bisa merupakan subsistem dari sebuah sistem.

2) Batasan (Boundary)

Penggambaran dari suatu elemen atau unsur mana yang termasuk di dalam sistem dan yang di luar sistem.

3) Lingkungan luar (Environment)

Segala sesuatu yang di luar sistem, lingkungan yang menyediakan asumsi, kendala dan input terhadap suatu sistem.

4) Penghubung (Interface)

Tempat di mana komponen atau sistem dan lingkungannya bertemu atau berinteraksi.

5) Masukan (Input)

Sumber daya (data, bahan baku, peralatan, energi) dari lingkungan yang dikosumsi dan dimanipulasikan oleh suatu sistem.

6) Keluaran (Output)

Sumber daya atau produk yang disediakan untuk lingkungan sistem oleh kegiatan dalam suatu sistem.

7) Penyimpanan (Storage)

Area yang dikuasai dan digunakan untuk penyimpanan sementara dan tetap dari informasi, energi, bahan baku dan sebagainya.

\subsubsection{Klasifikasi Sistem}

1) Sistem Abstrak dan Sistem Fisik

Sistem abstrak (abstract system) adalah sistem yang berisi gagasan atau konsep. Misalnya sistem teologi yang berisi gagasan tentang hubungan manusia dengan tuhan.

Sistem fisik (physical system) adalah sistem yang secara fisik dapat dilihat. Misalnya sistem komputer, sistem sekolah, sistem akutansi, dan sistem transportasi.

2) Sistem Deterministik dan Sistem Probabilistik

JURSIMA https://ejournal.giciku.ac.id/ Jurnal Sistem Informasi dan Manajemen
Sistem deterministik (deterministic system) adalah suatu sistem yang operasinya dapat diprediksi secara tepat. Misalnya sistem komputer.

Sistem probabilistik (probabilistic system) adalah suatu sistem yang tak dapat diramal dengan pasti karena mengandung unsur probabilitas. Misalnya sistem arisan dan sistem persediaan.

3) Sistem Tertutup dan Sistem Terbuka

Sistem tertutup (close system) adalah sistem yang tidak bertukar materi, informasi atau energi dengan lingkungan. Misalnya reaksi kimia dalam tabung yang terisolasi.

Sistem terbuka (open system) adalah sistem yang berhubungan dengan lingkungan dan dipengaruhi oleh lingkungan. Misalnya suatu perusahaan mengikuti eksistensi pasar agar eksitensinya tetap dapat dipertahankan.

4) Sistem Alamiah dan Sistem Buatan Manusia Sistem alamiah (natural system) adalah sistem yang terjadi karena alam (tidak dibuat oleh manusia). Misalnya sistem tata surya. Sistem buatan manusia (human made system) adalah sistem yang dibuat oleh manusia. Misalnya sistem komputer dan sistem mobil.

5) Sistem Sederhana dan Sistem Kompleks Berdasarkan tingkat kerumitannya, sistem dibedakan menjadi sistem yang sederhana (misalnya sepeda) dan sistem yang kompleks (misalnya otak manusia).

\subsubsection{Pengertian Data dan Pengolahan Data}

Data adalah sesuatu yang belum mempunyai arti bagi penerimanya dan masih memerlukan adanya suatu pengolahan. Data bisa berujut suatu keadaan, gambar, suara, huruf, angka, matematika, bahasa ataupun simbolsimbol lainnya yang bisa kita gunakan sebagai bahan untuk melihat lingkungan, obyek, kejadian ataupunsuatu konsep. 
Pengolahan data secara sederhana diartikan sebagai proses mengartikan data-data lapangan sesuai dengan tujuan, rancangan, dan sifat penelitian.minsalnya dalam rancangan penelitian kuantitatif, baik melalui pengolahan statistic deskriktif. Lain halnya dalam rancangan penelitian kualitatif, maka pengolahan data menggunakan teknik non statistic, mengingat data-data lapangan diperoleh dalam bentuk narasi atau kata-kata, bukan angka-angka. Mengingat data lapangna disajikan dalam bentuk narasi katakata, maka pengolahan datanya tidak bias dikuantifikasikan. Perbedaan ini harus dipahami oleh peneliti atau siapapun yang melakukan penelitian, sehingga penyajian data dan analis kesimpulan penelitian relevan dengan sifat atau jenis dan prosedur pengolahan data yang akan digunakan.

\subsubsection{Pengertian Data}

Kata data dalam bahasa inggris berasal dari kata datum dari bahasa latin yang berarti fakta. Kata tersebut bersifat flural,sebagaimana kata air, udara, dan semacamnya. Data (Tata Sutabri, S.Kom., MM, 2005) terbagi atas 2 (dua) bagian, yaitu:

1) Data bagi manusia adalah segala sesuatu yang dapat ditangkap oleh indra manusia.

2) Data bagi computer adalah segala sesuatu yang dapat dilambangkan, dikode kan atau didigitalisasikan kedalam lambang-lambang atau kode-kode yang dimengerti oleh komputer.

\subsubsection{Pengolahan Data}

Pengolahan data berarti memanipulasi data dan pengolahan data secara elektronik dengan menggunakan komputer. Tahap-tahap pengolahan data diantaranya adalah sebagai berikut:

JURSIMA https://ejournal.giciku.ac.id/

Jurnal Sistem Informasi dan Manajemen
1) Perekaman (Recording)

Tahap awal pengolahan data yaitu data hendaknya ditulis kedalam bentuk formulir untuk dijadikan dasar pengolahan.

2) Klasifikasi (Classifyng)

Merupakan pemberian suatu tanda atau identitas kepada data yang akan diolah apakah untuk suatu kelompok atau satu kelas.

3) Pengurutan (Sorting)

Setelah data diolah dan diidentifikasi maka data perlu diatur sedemikian rupa misalnya diurut menurut klasifikasinya.

4) Perhitungan (Calculating)

Merupakan langkah yang berfungsi memanipulasi data-data seperti pelaksanaan perhitungan-perhitungan.

5) Penyusunan Laporan (Summarzing)

Dilakukan penyimpulan atau pembuatan rekapitulasi laporan sesuai dengan yang diinginkan pengguna informasi.

6) Penyimpanan (Storage)

Penyimpanan data yang sejenis di dalam satu file sebagai referensi di masa yang akan datang. Hal ini sangat berguna nantinya sebagai proses perhitungan.

7) Pencari (Retrieving)

Proses mencari data dan mendapatkan kembali data dari file penyimpanan.

8) Pengadaan (Reproducing)

Pengadaan merupakan proses memperbanyak data sesuai dengan kebutuhan.

\subsubsection{Siklus Pengembangan Sistem}

Suatu proses pengolahan data terdiri dari tiga tahapan dasar yang disebut siklus pengolahan data (data processing cycle) yaitu input, processing dan output. Adapun gambar siklus pengolahan data adalah sebagai berikut :

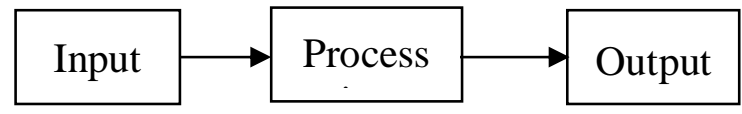


ISSN 2338-1523

E-ISSN 2541-576X

Volume 7 No. 1

Mei 2019

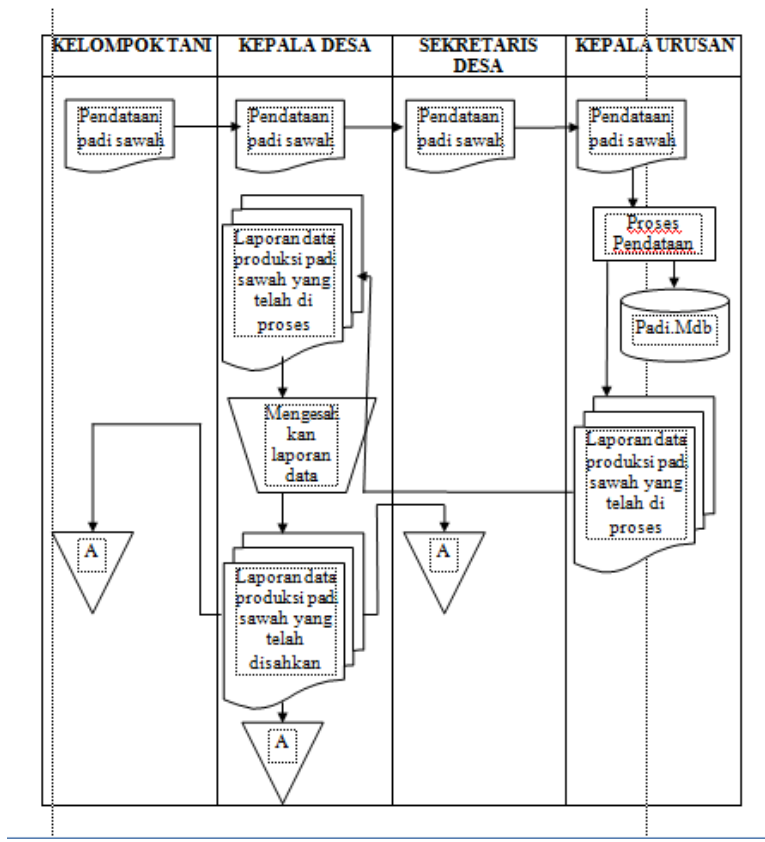

Gambar 2.1 Siklus Pengolahan Data Sumber : Jogianto Hartono, MBA, Ph.D, 1999.

Tiga tahap dasar dari siklus pengolahan data tersebut dapat dikembangkan lebih lanjut. Siklus pengolahan data yang dikembangkan (exepended data processing cycle) dapat ditambahkan tiga atau lebih tahapan lagi seperti origination, storage dan distribution, sebagaimana yang terlihat pada siklus pengolahan data yang sudah dikembangkan berikut ini:

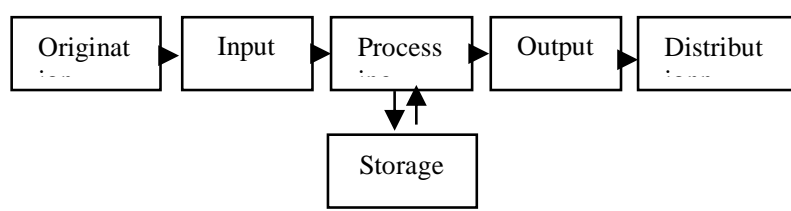

Gambar 2.2 Siklus Pengolahan Data yang Dikembangkan.

Sumber: Jogianto Hartono, MBA, Ph.D, 1999. Keterangan gambar :

1) Origination

Berhubungan dengan proses pengumpulan data yang biasanya merupakan proses

JURSIMA https://ejournal.giciku.ac.id/ Jurnal Sistem Informasi dan Manajemen pencatatan (recording) data ke dokumen dasar.

2) Input

Merupakan proses memasukkan data ke dalam proses komputer lewat alat Input (input device) untuk diolah.

3) Processing

Merupakan proses pengolahan data yang sudah dimasukan, dengan menggunakan alat pemroses (processing device), dapat berupa proses menghitung, membandingkan, mengklasifikasikan, mengurutkan, mengendalikan atau mencari di storage.

4) Output

Proses menghasilkan keluaran (output) dari hasil pengolahan data ke alat output (output device), yaitu hasilnya berupa informasi.

5) Distribution

Merupakan proses memberikan informasi kepada pihak yang membutuhkan.

6) Storage

Merupakan proses perekaman hasil pengolahan ke simpanan luar (storage), hasil dari pengolahan yang disimpan di storage dapat dipergunakan sebagai bahan masukan untuk proses selanjutnya.

\section{ANALISA SISTEM}

\subsection{Analisa Sistem yang di Usulkan}

Berdasarkan analisa terhadap sistem yang sedang berjalan, maka dilakukan perancangan sistem yang akan diusulkan dengan menggunakan peralatan komputer dengan bahasa pemrograman VB. Net untuk proses pengolahan data pemberian informasi pada Kantor Balai Benih Ikan (BBI) Talang Kemulun. Dengan digunakannya komputer beserta program ini diharapkan dapat memperlancar aktivitas seharihari, karena hal tersebut dapat memberikan keuntungan seperti dapat memberikan informasi tentang data padi sawah dengan cepat dan akurat, dapat meningkatkan aktivitas kerja, 
menghasilkan informasi dengan tingkat ketelitian yang tinggi, dapat mempercepat pengolahan data ikan. Adapun sistem informasi yang diusulkan adalah sebagaiberikut:

ALIRAN SISTEM INFORMASI YANG DI USULKAN

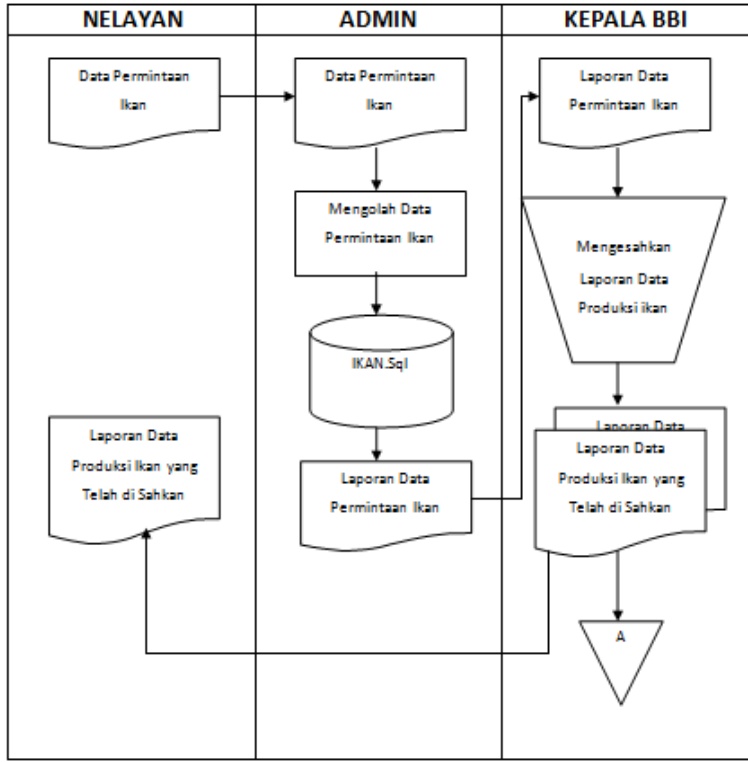

Gambar 3.1 ASI BARU

\section{HASIL}

\subsection{Desain Global}

Desain secara umum atau desain secara global dapat didefinisikan sebagai suatu gambaran, perencanaan dan pembuatan sketsa pengaturan dari beberapa elemen yang terpisah dalam satu kesatuan yang utuh untuk mencapai tujuan.

Perancangan sistem secara global yang akan dilakukan terjadi dari rancangan sistem baru dan struktur program.

\subsection{Struktur Program}

JURSIMA https://ejournal.giciku.ac.id/ Jurnal Sistem Informasi dan Manajemen
Struktur program adalah gambaran dari seluruh rangkaian modul-modul program yang saling terkait satu sama lain yang terlibat dalam proses perancangan sistem informasi. Pembuatan struktur program ini di maksudkan untuk mempermudah bagi kita dalam memahami keterkaitan dalam modul-modul program.

Adapun struktur program yang dirancang dalam pengolahan data produksi ikan pada Kantor Balai Benih Ikan (BBI) Talang Kemulun adalah sebagai berikut:

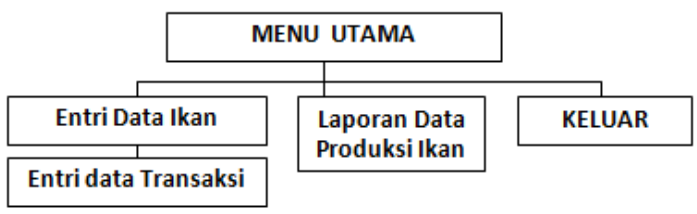

\section{Gambar 4.1 Struktur Program}

\subsubsection{Desain Secara Terinci}

Desain secara terinci merupakan rancangan dari analisa yang telah dilakukan dalam bentuk fisik (phisikal System design), adapun desain tersebut terdiri atas desain file, desain input, desain output dan logika program yang akan dituangkan dalam bentuk flowchart.

\subsection{Desain file}

File adalah kumpula dari record yang tersusun secara logis dimana record-record tersebut tersimpan pada mediapenyimpanan yaitu harddisk, yang digunakan oleh programer untuk keperluan program. Adapu rancangan file yang penulis gunakan dalam perancangan sistem pengolahan data padi sawah melalui kelompok tani adalah File Entry Data Ikan, File Entry Data Transaksi.

1. Desain File Entry Data Ikan

Tabel 4.1. Desain File Entry Data Ikan

$\begin{array}{ll}\text { Nama Database } & \text { : Ikan.Mdb } \\ \text { Nama Tabel } & \text { : Tblkan } \\ \text { Primary Key } & \text { : Kd_Ikan }\end{array}$


ISSN 2338-1523

E-ISSN 2541-576X

Volume 7 No. 1

Mei 2019

\begin{tabular}{|l|l|l|l|l|}
\hline No & $\begin{array}{l}\text { Field } \\
\text { Name }\end{array}$ & Type & Width & Description \\
\hline 1 & Kd_Ikan & Text & 3 & $\begin{array}{l}\text { Primary } \\
\text { key }\end{array}$ \\
\hline 2 & Jenis_Ikan & Varchar & 25 & \\
\hline
\end{tabular}

2. Desain File Entry Data Transaksi

Tabel 4.1. Desain File Entry Data Transaksi

Nama Database : Ikan.Mdb

Nama Tabel : : TbTransaksi

Primary Key : Kd_Transaksi

\begin{tabular}{|l|l|l|l|l|}
\hline $\begin{array}{l}\text { N } \\
\text { o }\end{array}$ & Field Name & Type & $\begin{array}{l}\text { Widt } \\
\text { h }\end{array}$ & $\begin{array}{l}\text { Descriptio } \\
\mathrm{n}\end{array}$ \\
\hline 1 & $\begin{array}{l}\text { Kd_Transaks } \\
\text { i }\end{array}$ & Text & 3 & $\begin{array}{l}\text { Primary } \\
\text { key }\end{array}$ \\
\hline 2 & Kd_Ikan & Text & 3 & F Key \\
\hline 3 & Jenis_Ikan & Varchart & 25 & \\
\hline 4 & Ukuran & Varchart & 25 & \\
\hline 5 & Jumlah & Varchart & 25 & \\
\hline 6 & Bulan & $\begin{array}{l}\text { DateTim } \\
\text { e }\end{array}$ & & \\
\hline
\end{tabular}

\subsection{Desain Input}

Desain Input adalah rancangan dari input data yang akan diproses. Dalam rancangan ini, juga menampilkan tombol proses.

1. Desain Input Entry Data Ikan

Entry Data Ikan

Pengolahan Data Produksi Ikan ada Kantor BBI

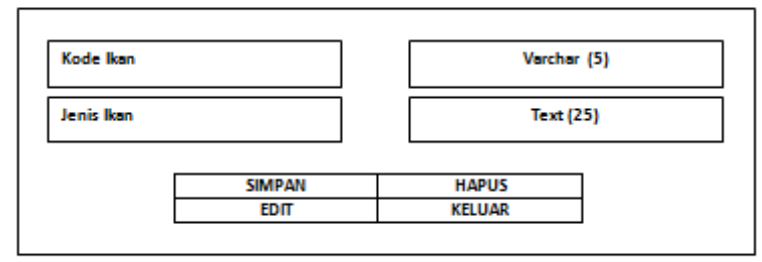

2. Desain Output Entry Data Transaksi

Entry Data Ikan

Pengolahan Data Produksi Ikan ada Kantor BBI

\begin{tabular}{|c|c|c|c|c|c|}
\hline $\begin{array}{c}\text { Kode } \\
\text { Transaksi }\end{array}$ & Kode Ikan & Jenis Ikan & Ukuran & Jumlah & Bulan \\
\hline $\mathrm{X}(\mathbf{5})$ & $\mathrm{X}(5)$ & $\mathrm{X}(\mathbf{2 5})$ & $X(25)$ & $\mathrm{X}(25)$ & DateTime \\
\hline
\end{tabular}

2. Desain input Entry Data Transaksi

JURSIMA https://ejournal.giciku.ac.id/

Jurnal Sistem Informasi dan Manajemen 


\section{Kesimpulan dan saran}

\subsection{Kesimpulan}

Dari hasil analisa dan pembahasan yang telah dilakukan pada bab-bab terdahulu penulis dapat menarik kesimpulan sehubungan dengan perancangan Sistem Pengolahan Data Produksi Ikan Pada Kantor Balai Benih Ikan (BBI) Talang Kemulun adalah sebagai berikut :

a. Sistem Pengolahan Data Produksi Ikan Pada Kantor Balai Benih Ikan (BBI) Talang Kemulun masih dilakukan secara manual. Semua penyimpanan data pada media penyimpanan yang telah ada kurang terjamin.

b. Sistem Pengolahan Data Produksi Ikan Pada Kantor Balai Benih Ikan (BBI) Talang Kemulun yang telah dirancang akan lebih dirasakan manfaatnya yaitu memberi informasi yang tepat dan akurat. Dengan demikin penyimpangan-penyimpangan atau kelemahan-kelemahan yang selama ini terjadi dapat diatasi.

\subsection{Saran}

Dari hasil penelitian sejak dari awal sampai akhir, penting bagi penulis memberikan saran sebagai berikut:

a. Diharapkan Kepada Kantor Kepala Desa Tanjung Pauh Mudik dapat memaksimalkan penggunaan program yang telah dibuat untuk pengolahan data produksi padi sawah melalui kelompok tani sebagai alat bantu untuk mempercepat pengolahan data agar tercipta hasil kerja yang efesien.

b. Melakukan pelatihan untuk tenaga kerja agar pada saat implementasinya tidak akan terjadi kesalahan, misalnya pada pemasukan data, JURSIMA https://ejournal.giciku.ac.id/ Jurnal Sistem Informasi dan Manajemen pengaksesan data serta pembuatan laporan yang dibutuhkan.

c. Pada penerapan sistem baru ini perlu adanya tenaga profesional dalam pengoperasian komputer.

d. Pada sistem informasi pengolahan data produksi padi sawah ini tentu saja masih ada kekurangan-kekurangan, untuk disarankan bagi penelitian selanjutnya untuk melanjutkan penelitian ini agar dapat menambah laporan dan informasi lainnya, sehingga lebih mendukung pengolahan data Produksi Ikan pada masa yang akan datang.

e. laporan-laporan yang akan dibuat untuk waktu untuk selanjutnya, dapat dilihat perbandingannya untuk laporan-laporan sebelumnya untuk membantu pengambilan keputusan.

\section{UCAPAN TERIMAKASIH}

Trimakasih kepada teman-teman yang telah memberikan semangat kepada saya.

\section{DAFTAR PUSTAKA}

Abdul Kadir. Pengenalan Sistem Informasi, Andi Yogyakarta, 2002.

Budi Sutedjo Dharma Oetomo, S.Kom.,MM."Perancangan dan pembangunan sistem informasi”, Andi Yogyakarta 2002.

Jogianto Hartono, MBA, h.D. "Pengenalan Komputer”, Andi, Yogyakarta, 1999.

Kusrini, M.Kom., dkk "Tuntunan Praktis Membangun Sistem informasi Akuntansi dengan visual basic dan Microsoft SQL Server", Andi Yogyakarta 2007. 
ISSN 2338-1523

E-ISSN 2541-576X

Volume 7 No. 1

Mei 2019
Madcoms "Pemrograman Tingkat Lanjut dengan VB. Net" Andy Yogyakarta 2005.
"Aplikasi Database dan Crystal Report pada Vb. Net" Andy Yogyakarta 2005

Tata Sutabri, S.Kom., MM. Sistem Informasi Manajemen, Andi, Jakarta, 2005.

Anton Athoillah,M.M,Dr,H,M, Dasar-dasar Manajemen, CV Pustaka Setia, Bandung,2010.

Subari \& Yuswanto. Pemrograman VB. Net, CERDAS PUSTAKA PUBLISHER, Jakarta, 2008.

Abdul Razak, VB. Net, INDAH, Surabaya,2004. 